\title{
DERIVED-IMPORTANCE PERFORMANCE ANALYSIS AS A TOOL TO IDENTIFY PRIORITIES FOR DESTINATION PRODUCT DEVELOPMENT
}

\author{
Josip Mikulić ${ }^{19}$
}

UDC / UDK: 338.48-44:005(497.6)

JEL classification / JEL klasifikacija: Z32

DOI: https://doi.org/10.22598/pi-be/2019.13.1.77

Preliminary communication / Prethodno priopćenje

Received / Primljeno: April 1, 2019 / 1. travnja 2019.

Accepted for publishing / Prihvaćeno za tisak: May 21, 2019 / 21. svibnja 2019.

\section{Summary}

Importance-performance analysis (IPA) is an analytical tool which is used to define priorities when it comes to improving certain attributes of products or services. In the present research note, IPA is applied to the context of a tourist destination in order to identify most important development priorities. More specifically, this study applies derived-importance IPA to Mostar, one of the most popular destinations in Bosnia and Herzegovina, and portrays how IPA can help to reveal critical areas of the tourist destination product.

Key words: importance-performance analysis, IPA, development priorities, tourism destination.

\section{INTRODUCTION}

Importance-performance analysis (IPA) is a prioritization tool that has been first introduced by Martilla and James in 1978 in an automotive context. Although this technique has originally been used in a product setting, IPA has been far more frequently applied to guide the improvement of various services like e.g. healthcare (e.g. Hawes and Rao, 1985; Aeyels et al., 2018), hotel services (e.g. Martin, 1995; Chu and Choi, 2000; Hemmington, Kim, \& Wang, 2018), or to even tourist destinations and their destination product as a whole (e.g. Go and Zhang, 1997; Jeng, Snyder, and Chen, 2019).

In order to conduct the analysis, IPA requires customer survey data which cover performance perceptions of salient attributes pertaining to focal products, services or destinations, on the one hand, as well as some measure of importance of the same

${ }^{19}$ Josip Mikulić, Ph.D., Associate Professor, Faculty of Economics and Business, University of Zagreb, Croatia, E-mail: jmikulic@efzg.hr 
attributes, on the other hand. Both measures of performance and importance for each attribute are then used to create a two-dimensional matrix that facilitates deriving different managerial recommendations based on the location of the attributes (Figure 1).

Figure 1. Original importance-performance analysis

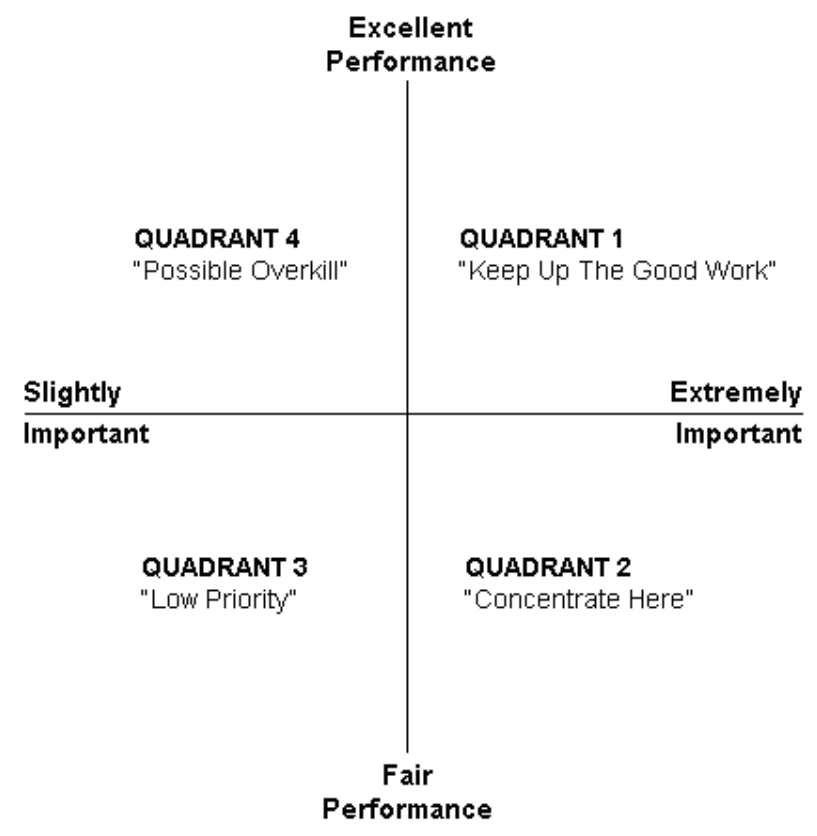

One of the most critical aspects when conducting an IPA is the operationalization of attribute importance-i.e. how importance is both defined and measured by the researcher. When reviewing available IPA publications, it becomes rather obvious that studies tend to neglect the fact that there at least two significantly different measures of attribute importance-i.e. direct and statistically derived measures. More importantly, these two different types of measures do not assess identical concepts, but rather different dimensions of the importance concept (see e.g. Jaccard, Brinberg, and Ackerman, 1986; Van Ittersum et al,. 2007). A few studies make an exception, whereas most recently, the issue has been highlighted by Mikulić et al. (2016).

Direct importance ratings assess the importance of attributes as perceived by the customer, thus reflecting his personal values and desires. In the literature, this type or dimension of importance is referred to as relevance. Since all previous experiences of a customer with a product, service or destination (which may range from none to many) influence these importance perceptions, just like the customer's knowledge about a product, service or destination which he has not yet used, direct ratings in fact indicate the extent to which the customer expects attributes to be provided at satisfying levels of performance. In this regard, relevance (i.e. importance which is measured with direct 
ratings), can be regarded as a relatively stable concept, similar to an attitude, but it may change over time, due to new consumption experiences or shifts in customer's needs and desires.

Although direct importance ratings have high face validity, their use is not uncommonly criticized. Such the informational value of direct importance ratings may be limited due to a lack of discriminatory power. This problem may arise in situations when respondents tend to rate everything important in surveys, which results in strongly positively skewed distributions of importance data, with little differences between attributes. It should, however, be acknowledged that this deficiency may be attributed to peculiarities of the research instrument used, not to the measure itself. Such, all attributes under investigation typically are very important (they may be the most salient ones), especially when lists of attributes in a questionnaire have been generated through qualitative techniques, like e.g. free-elicitation. In such cases, discriminatory power may be low, but, however, mean ratings still provide a good basis to rank attributes according to their relevance for the customer. Another point of criticism pertaining to direct ratings is poor external validity. Here, however, it is important to note that this apparent shortcoming may in fact be a consequence of invalid interpretation of direct ratings, and subsequently, the chosen approach for testing external validity. In particular, comparing direct ratings with statistically derived importance measures to judge upon the external validity of direct ratings cannot be regarded a valid approach, because these two kinds of measures assess different dimensions of importance.

In contrast to direct ratings, regression-based weights (or similar measures like partial correlation coefficients, path model effect sizes, or measures of variance decomposition), obtained by relating data about attribute-performance against an outcome variable like e.g. global/overall satisfaction, assess an attribute's importance in achieving this particular outcome. Several authors refer to this instance of importance as determinance (Myers and Alpert, 1968, 1977; Jaccard et al., 1986), with a significant difference towards relevance being that it is an inherently dynamic dimension of importance, as opposed to relatively stable and static measures of relevance measures. Direct and indirect measures of importance thus may significantly diverge, because an attribute's determinance is in fact influenced by its relevance (i.e. a customer is certainly more sensitive to variations in objective performance for attributes he considers more important - this is probably the reason why these two measures are typically regarded as exchangeable measures), but the attribute's determinance is also influenced by actual levels of attribute performance in an investigated setting (i.e. the importance of a quality attribute in evaluation and/or choice of a product/service depends on how the product/service actually performs with regard to the attribute). Finally, as Mikulić and Prebežac (2012) note, determinance of an attribute may also be influenced by levels of performances of other attributes under investigation (i.e. the product/service/destination has to be regarded as a whole). In their study, these authors use the intuitive example of flight safety to illustrative the relevance-determinance relationship. Although it is rather obvious that this attribute would yield very high importance ratings in a passenger satisfaction survey (i.e. direct importance ratings measuring relevance), the attribute would not necessarily exhibit a proportionally strong impact on overall satisfaction with 
a flight or the airline (i.e. statistically-derived scores measuring determinance), unless there actually occurred safety problems during a flight.

Accordingly, when using IPA, it is of utmost importance to distinguish between direct and indirect measures because they assess different dimensions of importance. More importantly, direct and indirect measures require different ways of interpretation and provide quite distinct implications. As Mikulić and Prebežac (2011) note, when using measures of relevance (e.g. direct ratings of importance), IPA will help to identify elements which are critical during the customer's choice phase, whereas IPA based on determinance points to critical attributes during the consumption phase.

\section{METHODOLOGY}

The objective of the present research note is to portray the application of determinance-based IPA in identifying destination development priorities. For this purpose, this study uses data which have been collected by the Institute for tourism Zagreb, as part of a wider study conducted in four destinations in the Federation of Bosnia and Herzegovina (FB\&H) - i.e. Mostar, Sarajevo, Neum and Medjugorje. Main aspects which have been covered by the study were mostly related to attitudes and expenditures of tourists coming to these destinations in the FB\&H. For the present study, only the data for Mostar have been used. Overall, a quota sample was used consisting of 879 respondents who were surveyed using a highly structured questionnaire. The data were collected during personal interviews which were conducted on several popular tourist locations and at hotels.

\section{ANALYSIS AND RESULTS}

A brief overview of main sample characteristics is provided in Table 1.

Table 1. Sample characteristics

\begin{tabular}{|l|l|l|}
\hline Visitor type & & \\
\hline & Same-day & $32 \%$ \\
\hline & Overnight & $28 \%$ \\
\hline Country of residence (Top 5) & & \\
\hline & B\&H & $26.9 \%$ \\
\hline & Croatia & $15.3 \%$ \\
\hline & Italy & $11.3 \%$ \\
\hline & Spain & $10.1 \%$ \\
\hline & Germany & $4.5 \%$ \\
\hline & Turkey & $4.5 \%$ \\
\hline Age & & \\
\hline & $\leq 25$ & $8.8 \%$ \\
\hline
\end{tabular}




\begin{tabular}{|l|l|l|}
\hline & $26-45$ & $55.1 \%$ \\
\hline & $46+$ & $36.2 \%$ \\
\hline Travel companionship & & \\
\hline & With partner only & $31.0 \%$ \\
\hline & With family/relatives & $13.9 \%$ \\
\hline & With friends & $34.6 \%$ \\
\hline & Alone & $20.6 \%$ \\
\hline Transportation mode & & \\
\hline & Car & $56.9 \%$ \\
\hline & Bus/coach & $30.5 \%$ \\
\hline & Other (incl. plane) & $12.7 \%$ \\
\hline
\end{tabular}

The data used for the derived-importance performance analysis (D-IPA) is presented in Table 2. Respondents expressed their satisfaction with 20 destination attributes (elements) on 5-point direct rating scales ranging from poor (1) to excellent (5). The satisfaction ratings were used as indicators of performance (AP) for the D-IPA. Additionally, using the same rating scales, respondents further expressed their overall satisfaction with their stay in Mostar. In order to obtain indicators of determinance for the D-IPA, this study calculated bivariate coefficients of correlation between the individual attribute satisfaction ratings, on the one hand, and the overall satisfaction rating, on the other hand (AI).

Table 2. Performance and determinance (derived importance) of destination attributes

\begin{tabular}{|l|l|r|r|}
\hline Code & Destination attribute & AP & AI \\
\hline e1 & Comfort level of accommodation & 4.28 & 0.27 \\
\hline e2 & Quality of service at the accommodation facility & 4.16 & 0.32 \\
\hline e3 & $\begin{array}{l}\text { Quality of gastronomic offer at the accommodation } \\
\text { facility }\end{array}$ & 4.28 & 0.37 \\
\hline e4 & Friendliness of accommodation staff & 4.43 & 0.25 \\
\hline e5 & $\begin{array}{l}\text { Availability of tourist brochures at the } \\
\text { accommodation facility }\end{array}$ & 4.08 & 0.32 \\
\hline e6 & Local transportation & 3.46 & 0.54 \\
\hline e7 & Signage of tourist attractions & 3.54 & 0.50 \\
\hline e8 & Parking possibilities & 3.10 & 0.54 \\
\hline e9 & Ease of wayfinding (pathways, road signs) & 3.56 & 0.62 \\
\hline e10 & Architectural and urbanistic picturesqueness & 4.17 & 0.51 \\
\hline e11 & Cleanliness & 3.36 & 0.51 \\
\hline e12 & Cultural sights & 4.13 & 0.29 \\
\hline e13 & Cultural events & 3.59 & 0.46 \\
\hline
\end{tabular}




\begin{tabular}{|l|l|r|r|}
\hline e14 & Gastronomic offer & 4.15 & 0.25 \\
\hline e15 & Entertainment offer & 3.83 & 0.49 \\
\hline e16 & Shopping possibilities & 4.16 & 0.40 \\
\hline e17 & Offer of souvenirs & 4.56 & 0.57 \\
\hline e18 & City-break suitability & 4.21 & 0.65 \\
\hline e19 & Personal safety & 4.38 & 0.38 \\
\hline e20 & Friendliness of local residents & 4.38 & 0.48 \\
\hline$G M$ & Grand mean & 3.99 & 0.43 \\
\hline
\end{tabular}

Using the data from Table 2 the D-IPA matrix was created (Figure 2). In order to divide the matrix into four quadrants, grand means of AP and AI were used as crosshairs.

In order to identify the most critical destination attributes requiring attention by the destination management, analysts should first focus at the upper-left quadrant of the D-IPA matrix since these attributes have above-average importance but, at the same time, the attributes perform below average.

Overall, seven attributes emerged critical in this regard-i.e. (e6) local transportation, (e7) Signage of tourist attractions, (e8) Parking possibilities, (e9) Ease of wayfinding (pathways, road signs), (e11) Cleanliness, (e13) Cultural events, and (e15) Entertainment offer. On a higher level of abstraction, one can say that most of the deficiencies pertain to the transportation infrastructure (e6, e7, e8, e9), and to entertainment possibilities (e13, e15).

In order to identify main strengths of the destination product the focus should be shifted to the upper-right quadrant of the D-IPA matrix. Again, attributes which are located here have above-average importance for the tourist's overall experience, but the attributes also perform above average. Overall, four attributes are located in this quadrant-i.e. (e10) Architectural and urbanistic picturesqueness, (e17) Offer of souvenirs, (e18) City-break suitability, and (e20) Friendliness of local residents. When developing communication strategies, these attributes are good candidates to be used promotional activities. 


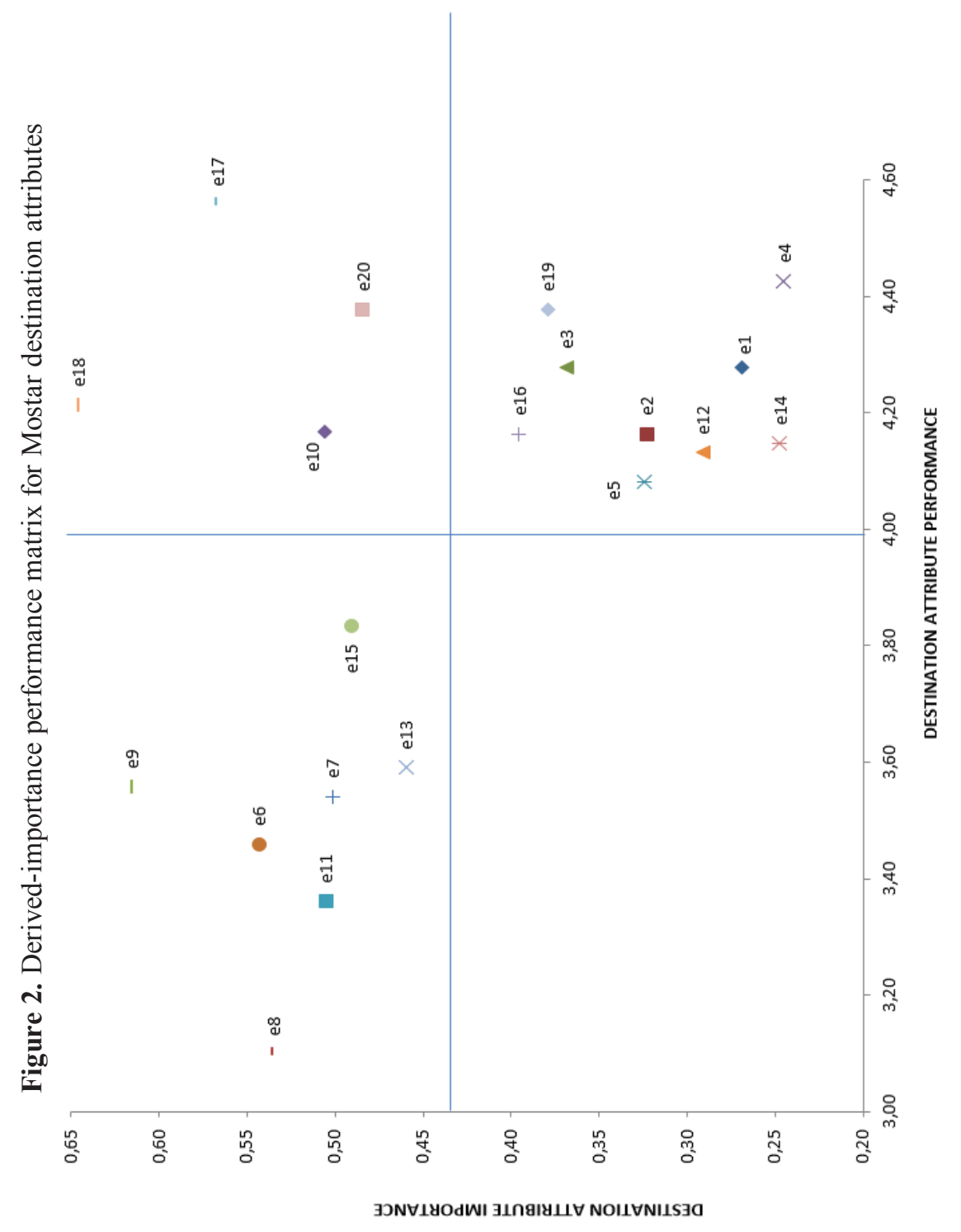




\section{CONCLUSION}

The aim of this research note was to portray the usefulness of derivedimportance performance analysis in developing improvement strategies for tourist destination products. In this regard, the results of this study can be used as an analytical foundation to guide improvement strategies with the goal to enhance the overall tourist experience in Mostar.

From a methodological standpoint, this paper intended to highlight the importance of distinguishing between IPA based on derived versus stated importance. The latter emerges more suitable when the researcher's goal is to detect improvement priorities within the context of destination choice, because relevance (as measured by stated importance measures) represents a rather stable, general perception of the importance of individual attributes. As such, relevance-based IPA points to critical attributes which are generally important to the customer. Conversely, derived importance, as a measure of determinance, helps the researcher to find those attributes which contribute most to a customer's outcome like overall experience or satisfaction based on actual consumption episodes. Accordingly, derived-importance IPA should be used by researchers as a tool to guide enhancement of the actual customer experience. Whenever possible, IPA should however encompass both measures of relevance and determinance, like in relevance-determinance analysis (Mikulić and Prebežac, 2011), to yield a more comprehensive informational basis to guide improvement strategies.

\section{REFERENCES:}

1. Aeyels, D., Seys, D., Sinnaeve, P. R., Claeys, M. J., Gevaert, S., Schoors, D., ... \& Vanhaecht, K. (2018). Managing in-hospital quality improvement: An importance-performance analysis to set priorities for ST-elevation myocardial infarction care. European Journal of Cardiovascular Nursing, 17(6), 535-542. DOI: $10.1177 / 1474515118759065$

2. Chu, R. K., \& Choi, T. (2000). An importance-performance analysis of hotel selection factors in the Hong Kong hotel industry: a comparison of business and leisure travellers. Tourism Management, 21(4), 363-377. DOI: 10.1016/S02615177(99)00070-9

3. Go, F., \& Zhang, W. (1997). Applying importance-performance analysis to Beijing as an international meeting destination. Journal of Travel Research, 35(4), 42-49. DOI: 10.1177/004728759703500407

4. Hawes, J. M., \& Rao, C. P. (1985). Using importance-performance analysis to develop health care marketing strategies. Journal of Health Care Marketing, 5(4).

5. Hemmington, N., Kim, P. B., \& Wang, C. (2018). Benchmarking hotel service quality using two-dimensional importance-performance benchmark vectors (IPBV). Journal of Service Theory and Practice, 28(1), 2-25. DOI: 10.1108/JSTP-06-2017-0103 
6. Jaccard, J., Brinberg, D., \& Ackerman, L. J. (1986). Assessing attribute importance: A comparison of six methods. Journal of Consumer Research, 12(4), 463-468. DOI: $10.1086 / 208530$

7. Jeng, C. R., Snyder, A. T., \& Chen, C. F. (2019). Importance-performance analysis as a strategic tool for tourism marketers: The case of Taiwan's Destination Image. Tourism and Hospitality Research, 19(1), 112-125. DOI: $10.1177 / 1467358417704884$

8. Martilla, J.A., \& James, J.C. (1977). Importance-performance analysis. Journal of Marketing, 77-79. DOI: 10.1177/002224297704100112

9. Martin, D. W. (1995). An importance/performance analysis of service providers' perception of quality service in the hotel industry. Journal of Hospitality \& Leisure Marketing, 3(1), 5-17. DOI: 10.1300/J150v03n01_02

10. Mikulić, J., \& Prebežac, D. (2011). Rethinking the importance grid as a research tool for quality managers. Total Quality Management \& Business Excellence, 22(9), 993-1006. DOI: 10.1080/14783363.2011.593857

11. Mikulić, J., \& Prebežac, D. (2012). Accounting for dynamics in attributeimportance and for competitor performance to enhance reliability of BPNNbased importance-performance analysis. Expert Systems with Applications, 39(5), 5144-5153. DOI: 10.1016/j.eswa.2011.11.026

12. Mikulić, J., Prebežac, D., \& Dabić, M. (2016). Importance-performance analysis: Common misuse of a popular technique. International Journal of Market Research, 58(6), 775-778. DOI: 10.2501/IJMR-2016-051

13. Myers, J.H., \& Alpert, M.I. (1968). Determinant buying attitudes: meaning and measurement. Journal of Marketing, 13-20. DOI: $10.1177 / 002224296803200404$

14. Myers, J.H., \& Alpert, M.I. (1977). Semantic confusion in attitude research: salience vs. importance vs. determinance. Advances in Consumer Research, 4(1), 106-110.

15. Van Ittersum, K., Pennings, J. M., Wansink, B., \& Van Trijp, H. C. (2007). The validity of attribute-importance measurement: A review. Journal of Business Research, 60(11), 1177-1190. DOI: 10.1016/j.jbusres.2007.04.001 


\title{
PRIMJENA ANALIZE DERIVIRANE VAŽNOSTI I IZVEDBE KAO TEHNIKE ZA IDENTIFIKACIJU RAZVOJNIH PRIORITETA DESTINACIJSKOG TURISTIČKOG PROIZVODA
}

\author{
Josip Mikulici ${ }^{20}$
}

\section{Sažetak}

Analiza važnosti i izvedbe (AVI) je analitički alat koji se primjenjuje s ciljem određivanja prioriteta prilikom poboljšanja obilježja/atributa proizvoda i usluga. U ovom kratkom radu se AVI primjenjuje u kontekstu turisticke destinacije kako bi se identificirala najvažnija razvojna područja. Preciznije, u radu se primjenjuje AVI koja se temelji na deriviranoj važnosti atributa na primjeru Mostara, jedne od najpopularnijih destinacija u Bosni i Hercegovini, te se prikazuje kako AVI može pomoći u otkrivanju kritičnih elemenata turističko-destinacijskog proizvoda. destinacija.

Ključne riječi: analiza važnosti i izvedbe, AVI, razvojni prioriteti, turistička

JEL klasifikacija: Z32

${ }^{20}$ Izv.prof.dr.sc. Josip Mikulić, Ekonomski fakultet, Sveučilište u Zagrebu, Hrvatska, E-mail: jmikulic@efzg.hr 